\title{
Isolation and Identification of Bacteria from Petroleum Polluted Soil in Auta Balefi, Nasarawa State
}

\author{
Olukeye $\mathrm{OO}^{1}$, Ajobiewe $\mathrm{HF}^{1 *}$, Ajobiewe $\mathrm{JO}^{2}$, Ogundeji $\mathrm{AA}^{3}$, Umeji $\mathrm{LC}^{4}$ \\ ${ }^{1}$ Bingham University Karu Nasarawa State of Nigeria \\ ${ }^{2}$ National Hospital Abuja,Plot 132 garki Central District, Nigeria \\ ${ }^{3}$ United State Department of Defence, Walter Reed Program- Nigeria. US Embassy, Abuja, Nigeria \\ ${ }^{4}$ Defence Reference Laboratory Asokoro, Abuja
}

DOI: $10.36347 /$ sjams.2020.v08i07.005

| Received: 19.06.2020 | Accepted: 27.06.2020 | Published: 08.07.2020

*Corresponding author: Ajobiewe H.F

This research work is aimed at highlighting the proportional differences in the number of organisms isolated from the various Petroleum product pollution sites. Engine oil and diesel are both petroleum products used in daily activities. These activities may lead to the pollution of the soil due to accidental spills. The pollution sites chosen for the research (two mechanic workshops, a diesel dispensing site and a diesel generator surrounding) were grossly polluted and therefore ideal for the research. From the pollution sites, Pseudomonas spp. Bacillus spp. Micrococcus spp., Staphylococcus spp., Aerococcus spp. were identified after macroscopic, microscopic and biochemical characteristics were analysed. The ability of the organisms to grow on agar containing the pollutants suggested their ability to degrade engine oil and diesel oil by using them as a carbon source. These bacteria therefor have the potential to be used for the breakdown of pollutants in bioremediation. Statistical analysis showed that there was no significant proportion in the number of bacteria present in the different pollution sites $(\mathrm{P}>0.05)$.

Keywords: Pseudomonas spp. Bacillus spp. Micrococcus spp., Staphylococcus spp., Aerococcus spp. Petroleum, Pollution, Soil.

Copyright @ 2020: This is an open-access article distributed under the terms of the Creative Commons Attribution license which permits unrestricted use, distribution, and reproduction in any medium for non-commercial use (NonCommercial, or CC-BY-NC) provided the original author and source are credited.

\section{INTRODUCTION}

The use of microorganisms in removing or detoxifying pollutants, mainly the contaminants of soil, water, or sediment which might threaten public health is a very important subject. Microorganisms are ubiquitous i.e. they can adapt, live and even thrive in all environments; this fact is the foundation on which this study is built on. Microbes are able to utilize a near infinite combination of electron donors and electron acceptors to drive their metabolism. In addition to these redox (oxidation/reduction) reactions, they have also developed a myriad of other strategies enabling them to detoxify their environment [1]. Bacteria, algae, fungi, and yeast have all been reported to degrade phenolic compounds heavy metals, pesticides, and petroleum along with a number of other environmental pollutants [2]. Bacteria are unicellular microorganisms that can thrive in many environments. They are prokaryotic in nature. The different bacteria species all possess diverse qualities and therefore can be found in a wide variety of environments and in extreme conditions.
Petroleum products constitute a large part of the pollution problem worldwide. The human activities that lead to the contamination of the soil are quite many. These include accidental spills on soil in mechanic workshops, filling stations etc. The most utilized petroleum products include; petrol, diesel, kerosene and engine oil. Several species of bacteria have been proven to have degradative potential against petroleum products. This study aims at identifying the species of bacteria that act on petroleum products. Soil is normally considered as the fine earth which covers land surfaces as a result of the in situ weathering of rock materials or the accumulation of mineral matter transported by water, wind, or ice. The distinctive feature of soil is that to this weathered mineral material is added organic material. This organic material may be both living and dead. It is this mixture of mineral and organic material which gives the soils their distinctive characteristics. Depending upon the context, the word "soil" may have very different meanings. A simple definition of soil is the material that plants grow in and which provides them with physical support, water, and nutrients. The most widely held view of the soil, however, is as a medium for plant growth and the provision of food and 
fiber directly through the intermediate stage of animals [3]. The soil is usually generated when rocks break up into their constituent parts. When a range of different forces acts on the rocks, they break into smaller parts to form the soil. These forces also include the impact of wind, water and the reaction from salts. Soil is basically classified into four types which include sandy soil, clay soil, loamy soil and silt. The different types of soil are differentiated by texture, structure, porosity, chemistry and colour. These properties are dependent on certain factors which include mineral particles, organic matter, water and air. Pollution is also a contributing factor to the chemical and physical properties of soil. Soil provides ecosystem services critical for life. Soil acts as a water filter and a growing medium; provides habitat for billions of organisms, contributing to biodiversity; and supplies most of the antibiotics used to fight diseases. Humans use soil as a holding facility for solid waste, filter for wastewater, and foundation for our cities and towns. Finally, soil is the basis of our nation's agroecosystems which provide us with feed, fibre, food and fuel. Soil is a vital part of the natural environment. It influences the distribution of plant species and provides a habitat for a wide range of organisms. It controls the flow of water and chemical substances between the atmosphere and the earth, and acts as source and store for gases (like oxygen and carbon dioxide) in the atmosphere. Soils not only reflect natural processes but also record human activities both at present and in the past [4]. This characteristic or function of soil is what makes the proper use and maintenance of the soil very important. Some changes in the soil will be of short duration and reversible, others will be a permanent feature of soil. Soil, together with the plant and animal life it supports, the rock on which it develops; its position in the landscape and the climate it experiences, form an amazingly intricate natural system more powerful and complex than any machine that man has created. Soil is utilized by exploiting its functions. The great importance of soils for the existence of humankind is clearly suggested by the term "culture", which is derived from the Latin word "colere" (to till). The exploitation of certain soil functions does not only create benefits but can also cause damage. When exploiting the soil it must always be borne in mind that the benefit from the use of one function can at the same time be detrimental to the use of another function. In the case of mining for instance, the discovery of crude oil in the soil for the production of various petroleum products is one of great importance and one which has brought about a lot of positive uses. Although this discovery was and is a positive event, the spills that occur as a result of the spill of raw crude oil and its products poses a huge threat to the health of the organism that are dependent on the soil being mined or where the products are being utilized, this in turn causes soil pollution. Pollution refers to the introduction by man into the environment of substances or energy liable to cause hazards to human health, harm to living resources and ecological systems, damage to structure or amenity or interference with legitimate uses of the environment. Pollution occurs when there is the potential for harm. Harm of man is not confined to physical injury but encompasses offence caused to any of his senses or harm to his property, therefore smells and noise which may not cause injury can constitute pollution. Harm to living organisms can include harm to their health or interference with the ecological systems of which they form a part [5]. There are various types of pollution which include; soil pollution, water pollution, air pollution, noise pollution, radioactive contamination, light pollution and thermal pollution [6]. These types of pollution all have grave effects on the environment and are believed to have the potential to bring about serious consequences that will affect every day human life if they are not treated with utmost urgency. The pollution of soil and water are considered to be the most important and prominent areas involved in environmental pollution as they are the types of pollution that most affect everyday life. Petroleum, also called crude oil, is a fossil fuel. Like coal and natural gas, petroleum was formed from the remains of ancient marine organisms, such as plants, algae, and bacteria. Millions of years of intense heat and pressure on these organic remains (fossils) have transformed into carbonrich substances we currently rely on as raw materials for fuel and a wide variety of products [7]. Crude oil is composed of hydrocarbons, which are mainly hydrogen (about $13 \%$ by weight) and carbon (about $85 \%$ ). Other elements such as nitrogen (about $0.5 \%$ ), sulfur $(0.5 \%)$, oxygen $(1 \%)$, and metals such as iron, nickel, and copper (less than $0.1 \%$ ) can also be mixed in with the hydrocarbons in small amounts (Elizabeth Morse, [7]. Petroleum resources exploration in Nigeria dates back to 1908, when German surveyors for the Nigerian Bitumen Corporation, began prospecting for Tar Sand deposit in the South-Western Nigeria. These pioneering efforts ended abruptly with the outbreak of the World War I in 1914. Exploration of petroleum resources did not begin until 1938, when Shell D'Arcy (a consortium of Iranian Oil Company (later British Petroleum) and Royal Dutch Shell) was granted a sole concessionary right over the whole country. However, World War II (1939-1945) terminated the initial oil exploration activities by Shell D'Arcy. Oil exploration in the Nigeria's Niger Delta resumed in 1946 after World War II and Shell D'Arcy drilled a number of oil exploratory wells in 1951. Mobil Producing (Nigeria) Ltd, a subsidiary of American Socony-Mobil Oil Company, obtained license to explore for oil and began operations in Nigeria in 1955 under the name Mobil Exploration Nigeria Incorporated (which was later incorporated as Mobil Producing Nigeria on June 16, 1969).The first commercial oil discovery in the Tertiary delta was confirmed at Oloibiri field in January 1956 by Shell D'Arcy (later Shell-British Petroleum) and a second oil field was later discovered at Afam. In February 1958, Shell British Petroleum (now Royal Dutch Shell) started exporting crude oil produced from Oloibiri and Afam 
oil field sat Port Harcourt. The giant Bomu oil field, which has estimated ultimate recovery (EUR) of 0.311 billion of barrels (BB) of oil and a total of 0.608 billion of barrels of oil equivalent (BBOE) including gas, was discovered southeast of Port Harcourt-Rivers State in 1958 [8]. Natural gas, crude oil, tars, and asphalt are types of petroleum hydrocarbons. The word petroleum means "rock oil" or "oil from the earth". Petroleum used in our daily life plays a vital role in our modern society. It is the main energy source for heating, transportation, and manufacturing, but acts as a raw material for plastic and synthetic rubber. Total Petroleum Hydrocarbons (TPHs) are used to describe mixtures of organic compounds found in or derived from crude oil that has the potential to be most toxic. It's made up of hydrogen and carbon but may also contain sulfur, nitrogen, heavy metals, and oxygen compounds. Most products that contain total petroleum hydrocarbons (TPHs) can burn easily. Some are clear or light coloured liquids that evaporate easily, and others are thick, dark liquids or semi-solids that do not evaporate and many of these products (gasoline, kerosene etc.) are oily. Modern society uses so many petroleum-based products (for example gasoline, kerosene, fuel oil, mineral oil, and asphalt), widespread environmental contaminants. Crude oil is measured in Barrels (bbls). A barrel of crude oil provides slightly more than 44 gallons of petroleum products.

\section{METHOD}

Four sites were selected for this study. Eight soil samples were collected from the sites (two samples from each site). The samples were collected in sterile bijou bottles and stored at $4^{\circ} \mathrm{C}$ in the laboratory before processing. One gram of each soil sample was weighed separately into different sterile test tubes containing $9 \mathrm{ml}$ of sterile distilled water and then stirred vigorously with a glass rod to blend the sample to make a stock of $10 \mathrm{ml}$. In a serial progression, $1 \mathrm{ml}$ of the fifth dilution factor was then withdrawn and discarded i.e. $10^{-1}, 10^{-2}, 10^{-3}$, $10^{-4}, 10^{-5 .}$. The media used was nutrient agar and nutrient broth and it was prepared according to manufacturer's instruction.

\section{HYPOTHESIS}

Ho: There is no significant proportion in the number of bacteria isolated from petroleum product waste sites.

Ha: There is significant proportion in the number of bacteria isolated from petroleum product waste sites.

\section{RESULTS}

A total of four pollution sites were examined including two mechanic sites ( $1 \& 2$ ) and two diesel pollution sites $(3 \& 4)$. Each sample was collected with duplicates and examined. Table 1 below shows the number of bacteria isolated from the various pollution sites. Table 2 below show the gram staining results of the isolated organisms. Table 3 below shows the results of the biochemical tests carried out according to [9]. The biochemical tests include catalase test, coagulase test, oxidase test, indole test, methyl red test and sugar ferntation tests. Table 4 below shows the results the various probable organisms and their characteristics.

Table-1: Bacterial count of various pollution sites in Auta Balefi, Nasarawa state

\begin{tabular}{|l|l|}
\hline Petroleum product waste site & Number of bacteria isolated $(\mathbf{c f u} / \mathbf{m l})$ \\
\hline Engine oil polluted site 1 & $2.6 \times 10^{7}$ \\
\hline Engine oil polluted site 2 & $2.48 \times 10^{7}$ \\
\hline Diesel Polluted site 3 & $1.16 \times 10^{7}$ \\
\hline Diesel Polluted site 4 & $1.36 \times 10^{7}$ \\
\hline
\end{tabular}

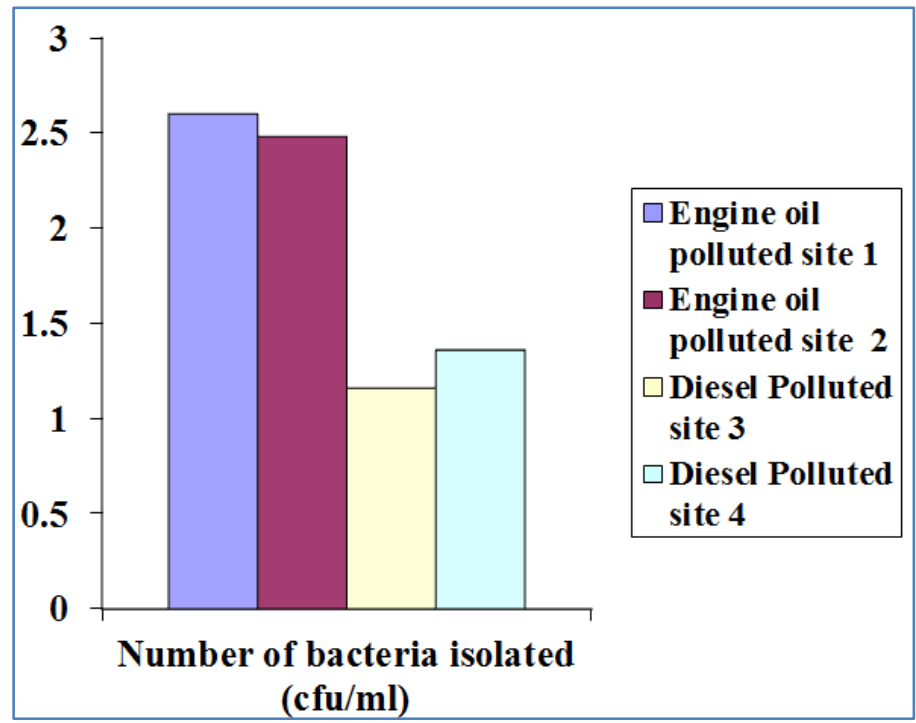

Fig-1 : Graph on the number of bacteria isolated in $\mathrm{cfu} / \mathrm{ml}\left(10^{7}\right)$ 
Table-2 : Gram staining results

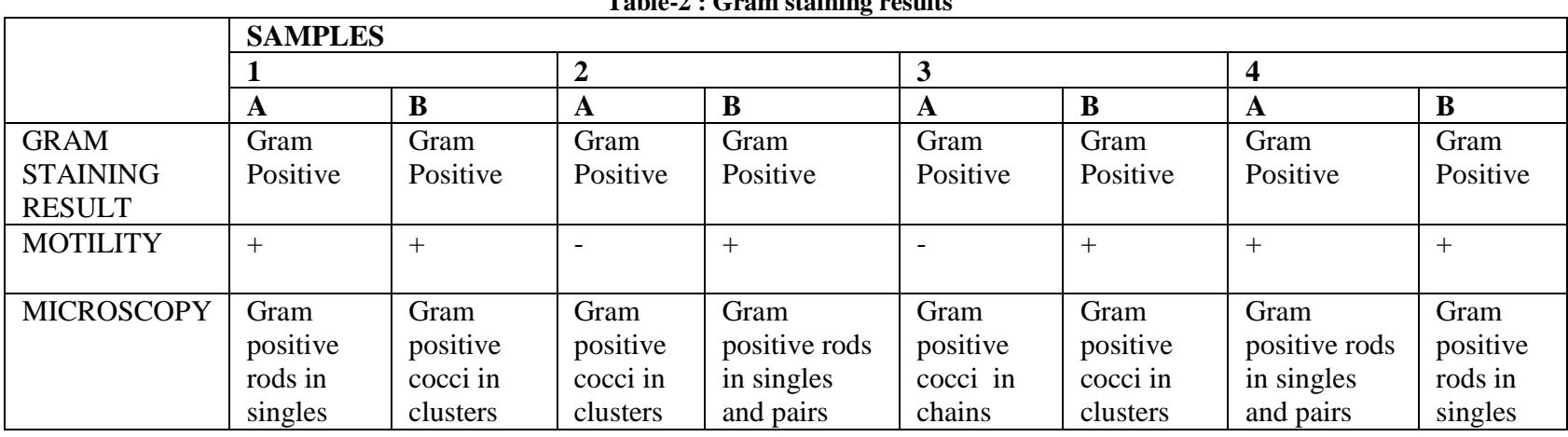

Table-3: Biochemical test results

\begin{tabular}{|c|c|c|c|c|c|c|c|c|}
\hline \multirow{3}{*}{$\begin{array}{l}\text { BIOCHEMICAL } \\
\text { PROCESSING }\end{array}$} & \multicolumn{8}{|c|}{ SAMPLES } \\
\hline & \multicolumn{2}{|c|}{1} & \multicolumn{2}{|c|}{2} & \multicolumn{2}{|c|}{3} & \multicolumn{2}{|c|}{4} \\
\hline & A & $\mathrm{B}$ & A & $\mathrm{B}$ & A & $\mathrm{B}$ & $\mathrm{A}$ & $\mathrm{B}$ \\
\hline COAGULASE TEST & - & - & + & - & - & - & - & - \\
\hline CATALASE TEST & - & + & + & - & - & + & - & - \\
\hline OXIDASE TEST & + & - & - & + & - & - & + & + \\
\hline $\begin{array}{l}\text { INDOLE } \\
\text { TEST }\end{array}$ & + & - & - & - & - & - & - & + \\
\hline METHYL RED TEST & - & - & - & - & - & - & - & - \\
\hline \multicolumn{9}{|c|}{ SUGAR FERMENTATION } \\
\hline GLUCOSE & + & + & + & + & + & + & + & + \\
\hline MALTOSE & - & + & - & - & + & + & - & - \\
\hline LACTOSE & - & - & + & - & + & - & - & - \\
\hline SUCROSE & - & + & + & - & + & + & - & - \\
\hline
\end{tabular}

Table-4: Suspected organisms and their characteristics

\begin{tabular}{|c|c|c|c|c|c|c|c|c|}
\hline \multirow[t]{3}{*}{ Characteristics } & \multicolumn{8}{|l|}{ Samples } \\
\hline & \multicolumn{2}{|l|}{1} & \multicolumn{2}{|l|}{2} & \multicolumn{2}{|l|}{3} & \multicolumn{2}{|l|}{4} \\
\hline & $\mathbf{A}$ & B & $\mathbf{A}$ & $\mathbf{B}$ & $\mathbf{A}$ & B & $\mathbf{A}$ & B \\
\hline \multicolumn{9}{|c|}{ MORPHOLOGY ON AGAR } \\
\hline Nutrient agar & $\begin{array}{l}\text { Colorless, } \\
\text { large, } \\
\text { opaque, } \\
\text { flat } \\
\text { colonies. }\end{array}$ & $\begin{array}{l}\text { Bright } \\
\text { yellow, } \\
\text { round, } \\
\text { moderately } \\
\text { raised } \\
\text { colonies }\end{array}$ & $\begin{array}{l}\text { Whitish, flat } \\
\text { round, } \\
\text { colonies. }\end{array}$ & $\begin{array}{l}\text { Yellowish } \\
\text { green, flat, } \\
\text { round } \\
\text { colonies. }\end{array}$ & $\begin{array}{l}\text { Milky } \\
\text { opaque, } \\
\text { round } \\
\text { colonies. }\end{array}$ & $\begin{array}{l}\text { Bright } \\
\text { yellow, } \\
\text { round, } \\
\text { moderately } \\
\text { raised } \\
\text { colonies }\end{array}$ & $\begin{array}{l}\text { Yellowish } \\
\text { green, flat, } \\
\text { round } \\
\text { colonies. }\end{array}$ & $\begin{array}{l}\text { Colourless, } \\
\text { large, } \\
\text { opaque, } \\
\text { flat } \\
\text { colonies. }\end{array}$ \\
\hline $\begin{array}{l}\text { Nutrient agar } \\
+ \text { Pollutant }\end{array}$ & $\begin{array}{l}\text { Colorless, } \\
\text { large, } \\
\text { opaque, } \\
\text { flat } \\
\text { colonies. }\end{array}$ & $\begin{array}{l}\text { Bright } \\
\text { yellow, } \\
\text { round, } \\
\text { moderately } \\
\text { raised } \\
\text { colonies }\end{array}$ & $\begin{array}{l}\text { Whitish, flat } \\
\text { round, } \\
\text { colonies. }\end{array}$ & $\begin{array}{l}\text { Yellowish } \\
\text { green, flat, } \\
\text { round } \\
\text { colonies. }\end{array}$ & $\begin{array}{l}\text { Milky } \\
\text { opaque, } \\
\text { round } \\
\text { colonies. }\end{array}$ & $\begin{array}{l}\text { Bright } \\
\text { yellow, } \\
\text { round, } \\
\text { moderately } \\
\text { raised } \\
\text { colonies }\end{array}$ & $\begin{array}{l}\text { Yellowish } \\
\text { green, flat, } \\
\text { round } \\
\text { colonies. }\end{array}$ & $\begin{array}{l}\text { Colourless, } \\
\text { large, } \\
\text { opaque, } \\
\text { flat } \\
\text { colonies. }\end{array}$ \\
\hline Shape & Rod & Cocci & Cocci & Rod & Cocci & Cocci & Cocci & Rod \\
\hline Motility & + & + & - & + & - & + & + & + \\
\hline \multicolumn{9}{|c|}{ Biochemical Tests } \\
\hline Coagulase Test & - & - & + & - & - & - & - & - \\
\hline Catalase Test & - & + & + & - & - & + & - & - \\
\hline Oxidase Test & + & - & - & + & - & - & + & + \\
\hline $\begin{array}{l}\text { Indole } \\
\text { Test }\end{array}$ & + & - & - & - & - & - & - & + \\
\hline $\begin{array}{l}\text { Methyl Red } \\
\text { Test }\end{array}$ & - & - & - & - & - & - & - & - \\
\hline \multicolumn{9}{|c|}{ Sugar Fermentation } \\
\hline Glucose & + & + & + & + & + & + & + & + \\
\hline Maltose & - & + & - & - & + & + & - & - \\
\hline Lactose & - & - & + & - & + & - & - & - \\
\hline Sucrose & - & + & + & - & + & + & - & - \\
\hline $\begin{array}{l}\text { Probable } \\
\text { Organism }\end{array}$ & $\begin{array}{l}\text { Bacillus } \\
\text { Spp. }\end{array}$ & $\begin{array}{l}\text { Micrococcus } \\
\text { Spp. }\end{array}$ & $\begin{array}{l}\text { Staphylococcus } \\
\text { Spp. }\end{array}$ & $\begin{array}{l}\text { Pseudomonas } \\
\text { Spp. }\end{array}$ & $\begin{array}{l}\text { Aerococcus } \\
\text { Spp. }\end{array}$ & $\begin{array}{l}\text { Micrococcus } \\
\text { Spp. }\end{array}$ & $\begin{array}{l}\text { Pseudomonas } \\
\text { Spp. }\end{array}$ & $\begin{array}{l}\text { Bacillus } \\
\text { Spp. }\end{array}$ \\
\hline
\end{tabular}


The organism isolated was proved to be Bacillus spp., Pseudomonas spp., Micrococcus spp., Staphylococcus spp., Aerococcus spp. These organisms are believed to have degradative ability because they grew in plates containing petroleum products

\section{DiscUSSION}

The effects of petroleum on the state of soil and soil dependent organisms has been proven though literature review, observation and analysis to be negative in the course of this research. The negative effects the petroleum products have on the ecosystem of the soil environment cannot be over emphasized. However, this research along with some previous research done on similar topics proves that there is hope for rehabilitation of the environments polluted by petroleum products. This hope comes in the form of bioremediation and biodegradation - The ability of microorganisms to utilize these pollutants with the production of non-toxic substances as by products. In this research, Bacillus spp. ,Pseudomonas spp. , Micrococcus spp. , Staphylococcus spp. , Aerococcus spp. were found to be present in the soil samples the soil samples after various biochemical, microscopic and morphological characters were observed. The use of nutrient agar containing petroleum products made according to the method of [10] as a medium for the growth of the organisms and the ability of the organisms to survive and thrive on this medium further proves that they have the ability to utilize the pollutants (engine oil and diesel) as their energy source and in turn, degrade them. It was proved that there is a significant proportion in the number of bacteria present in diesel pollution sites compared to engine oil polluted sites. This was proven by carrying out statistical analysis using Chi square where the p-value is 0.157 which is greater than 0.05 disproving the null hypothesis of the study and proving the alternate hypothesis stating that there is a significant proportion in the number of bacteria present in the various pollution sites. These organisms therefore, have the potential to be used for the degradation and clean-up of petroleum product based pollutants. The research also showed a higher number of organisms present in soils polluted by engine oil than the soil polluted by diesel through the colony count methods. The research was not without its challenges but was overall seen to prove that there is truly hope for areas grossly polluted by petroleum products.

\section{CONCLUSiOnS}

The probable organisms isolated from the soil include Bacillus spp., Pseudomonas spp., Micrococcus spp., Staphylococcus spp, Aerococcus spp. The organisms were identified using biochemical, macroscopic and microscopic methods. The engine oil polluted samples contained more organisms than the diesel oil samples.

\section{REFERENCES}

1. Heerden E, Williams P, Ojo E, Kuloyo K and Posthumus R. Bioremediation, Small solutions to big problems. Natural and agricultural Sciences. 2013.

2. Wasi S, Tabrez, S and Ahmad M. Use of Pseudomonas spp. for the bioremediation of environmental pollutants: a review. Environmental Monitoring and Assessment: An International Journal Devoted to Progress in the Use of Monitoring Data in Assessing Environmental Risks to Man and the Environment. 2015: 1-5.

3. Nortcliff S, Hulpke H, Claus BG, Konstantin T, Knoop G, Bredemeier M and Hubert SB. Soil, 1 Definition, Function, and Utilization of Soil. Ullman's Encyclopedia of Industrial Chemistry. 2017; 3: 399-419.

4. Mishra RK, Mohammad N and Roychoudhury N. Soil pollution: Causes, effects and control. Jabalpur, India.2015.

5. Appannagari RR. Environmental pollution causes and consequences: a study. North Asian International Research Journal of Social Science \& Humanities. 2017; 3(8): 151-161.

6. Biology Online. Biology Online Dictionary. 2008; Retrieved December 5, 2018, from www.biologyonline.org: online.org/dictionary https//www.biology-

7. Elizabeth Morse AT. Petroleum. (E. E. Jeannie Evers, Ed.).2018. Retrieved from www.nationalgeographic.org:

https://www.nationalgeographic.org/encyclopedia/p etroleum/

8. Ite A. Petroleum Exploration and Production: Past and Present Environmental Issues in the Nigeria's Niger Delta. American Journal of Environmental Protection. 2013; 78-90.

9. Cheesbrough M. District Laboratory Practices in Tropical countries (1st ed.). Edingbrough building, Canbrigde, United Kingdom: Cambridge University Press. Environment. Journal of Applied Sciences and Environmental Management. 2005; 14(1): 39-42.

10. Kaur J, Adamchuk VI, Whalen JK and Ismail AA. Development of an NDIR CO2 sensor-based system for assessing soil toxicity using substrateinduced respiration. Sensors. 2015; 4734-4748.

11. Adewoyin OA, Hassan AT and Aladesida A. The impacts of auto-mechanic workshops on soil and groundwater in Ibadan metropolis . African Journal of Environmental Science and Technology. 2013: 891-898.

12. Ross JP, Winn LA and Havens KE. Bioremediation and coastal wetlands, a report from a technical symposium on bioremediation of coastal wetlands following an oil spill. Pensacola Beach, Florida, United States of America.2010.

13. Agnieszka $\mathrm{M}$ and Piotrowska-Seget $\mathrm{Z}$. Bioaugmentation as a strategy for cleaning up of soils contaminated with aromatic compounds. In M. Agnieszka, \& Z. Piotrowska-Seget, Microbiological Research. 2010; 165, 363-375). 
Elsevier. $\quad$ Retrieved from https://www.sciencedirect.com/science/article/pii/S 0944501309000585

14. Adipah S. Introduction of Petroleum Hydrocarbons Contaminants and its Human Effects. Journal of Environmental Science and Public Health.2019; 1(3), 1-9.

15. Kadafa AA, Zakaria PM and Othman F. Oil Spillage and Pollution in Nigeria: Organizational Management. Journal of Environment and Earth Science. 2012; 2(4): 22.

16. There are no sources in the current document.

17. Nigerian National Peroleum Corporation. (2018, december). www.nnpc.com. Retrieved december 13 , 2018 , http://nnpcgrou.com/nnpcbusiness/businessinfo/oil andgasinnigeria/industryhistory.aspx

18. Abioye OP, Amaefule PO and Aransiola SA. Screening of Bacterial Consortium Isolated from Oil Contaminated Soil for Its Potential to Degrade Crude Oil. Advanced Science Focus. 2013; 1, 1-4.

19. Edwin-Wosu NL and Albert E. Total Petroleum Hydrocarbon Content (TPH) As an Index Assessment of Macrophytic Remediation process of a Crude Oil Contaminated Soil.2010.

20. Khan K, Naeem M, Arshed JM and Asif M. Extraction and Characterization of Oil Degrading Bacteria. Journal of Applied Sciences. 2006; 6(10): 2302-2306. 